\title{
Development of regional transport and logistics systems in the transformation of Russia's role in global value chains
}

\author{
Natalia Verbitskaya ${ }^{1, *}$ \\ ${ }^{1}$ Ural State University of Economics, 620144, March 8, 62, Ekaterinburg, Russia
}

\begin{abstract}
This article discusses the transformational capabilities of regional transport and logistics systems in the context of global value chains development, the so-called GVCs (Global value chains) [1], also related to the mining industry in Russia. The GVCs in the world economy are associated with increasing the efficiency of using national economies resources, creating and maintaining new jobs, increasing welfare and political stability, considered in the context of sustainable global development.
\end{abstract}

\section{Introduction}

The participation of any country in global value chains (GVCS) is directly related to the development of trade logistics. According to the World Bank report [1] developed economic countries also occupy leading positions in the sphere of transport logistics. Economic reforms and investments in developed countries are associated with the development of logistics systems and the improvement of logistics workforce competence. The main purpose of this study is to consider the processes of Russia's participation in the GVCs. According to the above-mentioned World Bank report, Russia today has a raw material role in world processes with a high degree of participation [1, p.2], which is also associated with the mining industry.

Russia's role in the GCVs is determined by global factors, including geographical location and resource availability. At the same time, the economic development strategy of Russia, set out in a number of documents of recent years, is focused on an innovative way to transform the economy. Then there is a need to consider how the factors that determine the role and position of Russia in the GVCs can be directed to innovative development tracks. In this regard, an increasing role is played by regional transport and logistics systems, activities of which are closely linked to a favorable geographical location. Development opportunities are associated with the formation of human resources competence in the logistics industry. A striking example of such territories in Russia is the Ural region with a pronounced Eurasian geographical location and the presence of developed transport and logistics systems associated with the extractive industries of the economy.

\footnotetext{
* Corresponding author: n.o.verbitskaya@usue.ru
} 


\section{Materials and methods}

The country's position in global value chains is related to the level of economic development. According to the World Bank report [1], logistics efficiency in high-income countries is $48 \%$ higher than in low-income countries. Logistics services are considered as the core of global trade. What investments are important for improving the logistics efficiency of countries that contribute to the world trade development? First of all, it is infrastructure development, as noted in the World Bank group report dated July 24, 2018 "Building links to improve competitiveness" [2]. Development involves the simplification of transport and trade procedures, infrastructure development, and the introduction of modern services and modern information platforms.

To analyze the dynamics of competitiveness, the logistics performance index (LPI) is calculated once every two years, which measures the degree of supply efficiency, providing companies with access to national and international markets. Russia, according to the 2018 LPI, ranked 75th [2]. Among the main problems of logistics development around the world is the lack of labor force in this area. Both developed and developing countries face this problem [3]. The lack of labor resources in logistics in the world is associated with a shortage of professional managers-logisticians at various levels, as well as a shortage of workers, such as truck drivers. The problem is also relevant for international transport in Russia. In our article, we will pay special attention to the problems of regional and international road carriers. This category of enterprises, along with railway transport, is the basis for the development of GVCs in Russia. It should be noted, that other global logistics issues related to cyber threats to information logistics platforms and services, as well as reducing $\mathrm{CO}_{2}$ emissions and protecting the environment from transport pollution, are also relevant for Russia.

The greatest interest for the context of our research is to consider the role of Russia in global value chains. The World Bank 2020 report, in the analysis of trade as a development tool in the era of the GVCs, examines the essence of the latter, which is a division between different countries of the global production process. Each country does not manufacture the entire product, but rather specializes in specific tasks, such as the production of raw materials and inputs in the form of services. Countries are divided into "raw" countries and countries with a high level of technology development that supply various types of services, specializing in the production of components, semi-finished products and, finally, countries with cheap labor that assemble finished products. The stability of global value chains is determined by fundamental economic factors [3]. The first axis of global factors is geographical location, resource availability, development institutions, and market size. The second axis is global production and distribution networks, policy measures aimed at the relevant tasks, such as employment growth, poverty reduction, environmental development, and overcoming inequality [1]. These two axes determine the driving forces of hyperspecialization of countries in the formation of global value chains. In the analysis of the World Bank group, two positions are of interest. The first is a map of the world [1, p. 2], which indicates the degree and role of each country's participation in global value chains as of August 2019; the second is a diagram of the dynamics of changes in the role of countries in the GVCs $[1$, p.5]. The degree of participation of each country in global value chains varies from limited participation in the supply of raw materials to innovative activities. We are most interested in Russia's position on this map, as it reflects the trends of economic development in the global economic space. On the map, Russia is assigned with the role of a world resource base with a high degree of participation. It is important that none of the territories on the map of Russia is marked at least as a zone of developed manufacturing industry, and even more so as a zone of innovative activity. This role is assigned to Europe and the United States. 
Leaving aside the political aspect of this analysis, we will take the tool of global value chains as the driving force of global economic development. In the given scheme [1, p. 5] in the same report, the transition lines from raw materials to more complex models of participation in GVCs are sufficiently justified, which is the basis of the state national policy of a number of countries.

We objectively accept that the main global factors that are shaping Russia's role in the GVCs today are the availability of resources and geographical location. The prospects for transforming this role in the future determine the current vectors of transport and logistics systems development focused on the international market. This is due to modern logistics services, infrastructure, basic connectivity based on information and communication technologies and modern range of information and communication services.

Let's formulate the main question of the research: how can Russia's two main advantages - favorable geographical position at the junction of Europe and Asia and resource availability - ensure the sustainability of the transformation of the role in the GVCs from raw materials participation to the development of the basis of modern logistics technologies?

To answer this question, it is necessary to substantiate the possibilities and conditions for the transformation of global factors that shape Russia's role in the GVCs - resource availability and geographical location - in the direction of changing Russia's role from raw material participation to technological and further to innovation participation. This path is designated as a priority for Russia's national development. Based on the concept of the development of world GVCs, presented by the World Bank group [2], one of the leading ways of this change is the development of logistics.

A number of studies by Russian and foreign authors are devoted to the development and changing role of Russia in global value chains, as well as in world trade. The works suggest various ways and tools for transforming the state investment and technological policy aimed at improving the efficiency of production, logistics, and social processes, which will eventually lead to a change in the position of the state in the world economic space $[4,3]$.

In a comparative assessment of the participation of the European Union and Russia in the world GVCs by the share of intermediate product consumption in exports [5], Russia has the world's largest index of production participation in the economy of other countries, defined as raw materials. This is not a good indicator when the Russian economy is characterized by the highest relative dependence on foreign markets and the state of foreign economies. Only intermediate and final products create material prerequisites for strengthening Russia's place in global industrial production and cross-border relations.

An interesting approach is to analyze the dynamics of the development of GVCs from the perspective of restructuring and reconfiguration of global supply chains in developing economies based on cyclical and structural factors [6]. Thus, [7] notes that the main stakeholders in strengthening global processes of division and specialization of production at the global level are developing countries such as China, Vietnam, and Mexico. In Russia, the share ratio between domestic and previously imported products in the form of goods and services (foreign) in gross exports is approximately similar to that of the United States, but still with a smaller share of foreign value added. In general, there are regional disproportions in economic and social development in Russia, which affect the uneven reproduction and development of scientific, technical and human potential. Thus, a number of studies have noted not only a positive but also a negative GVCs impact on the country's economy, which is associated with a small contribution of the cost from GVCs to GDP, income repatriation, and the risks of increasing technological underdevelopment. Since participation in global technological chains does not guarantee the transfer of technologies. 
In addition, the social and environmental consequences of participation in global value chains are associated with their impact on employment and health conditions [8].

An important conclusion in the research is the inclusion of political prerequisites for the formation of Russia's role in the GVCs, associated with their inclusion as key elements in the strategy of state and regional development, creating conditions for regions participation in global value chains to create a reliable environmental and social management base. It is assumed that the state should play a key role in the problem of increasing the efficiency of integration of Russian business in the GVCs due to special policy of regional development in relation to different degrees of regional economies integration in the GVCs [9].

In the sphere directly related to transport and logistics in the Russian Federation, the following picture is observed: export of transportation services in 2018 amounted to \$ 1,160 million, and for 9 months of 2019 - \$ 623 million, of which $\$ 537$ million - road freight transport. According to the data provided by the Ural branch of the Association of International Carriers (ASMAP) for the regions of the Ural Federal District and the Perm Territory, the export of road transport services only for 2018 is shown in figure 1 in million US dollars.

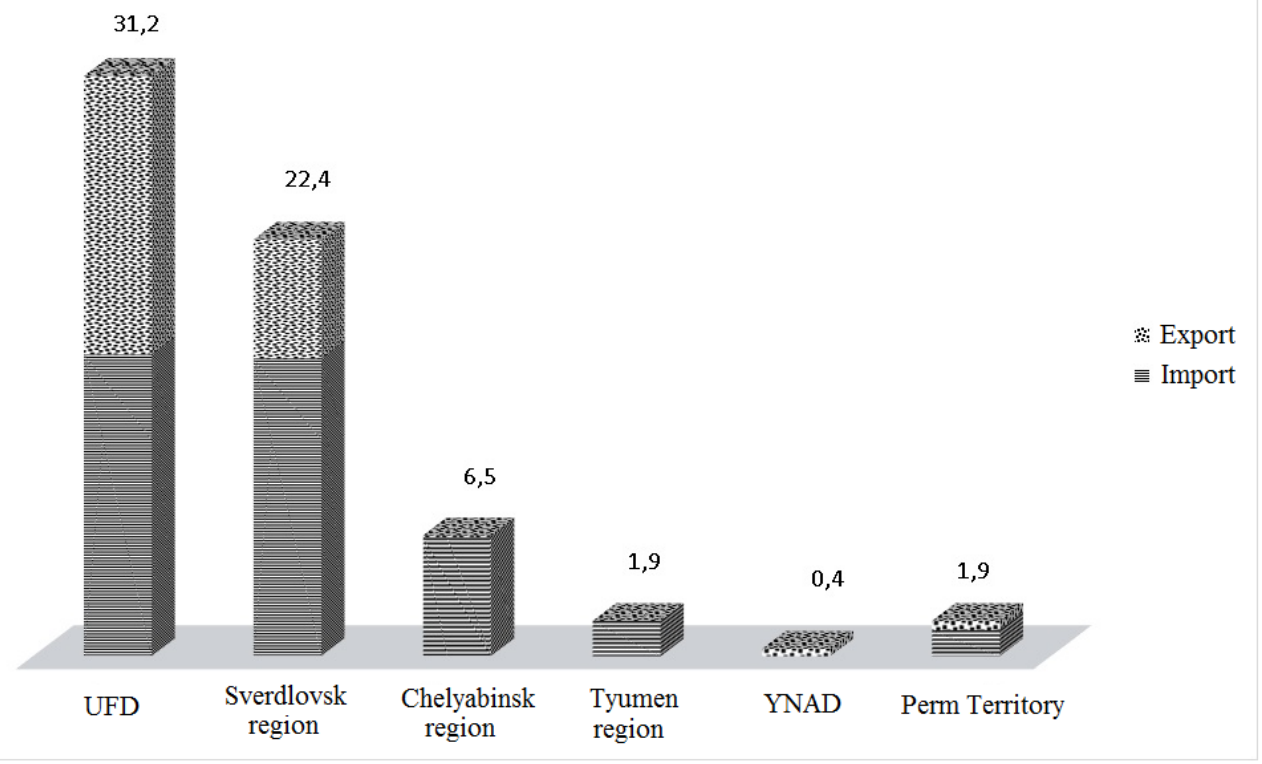

Fig. 1. Export of transport services to the regions of the Ural Federal District and Perm Territory in 2018, million US dollars

Transport services export results for the Ural Federal District in 2018 (target year for determining the world logistics performance index (LPI)) amounted to 31 million 231 thousand US dollars. In 2019-2020, the volume of cargo transportation exports in the Ural region remains quite high.

\section{Results and discussion}

The data provided by the World Bank experts, as well as theoretical studies, demonstrate the existing raw material role of Russia in the GVCs, including with a high 
share of the mining industry. Answering the question about the possibilities of transforming this raw material role, let's consider at first glance the auxiliary factor of development transport logistics. Along with the fact that transport logistics is an indicator of the strength of Russia's entry into the GVCs, it has a significant potential to change the role in the direction of transition to high-tech services. We are talking about the development of regional logistics systems in the direction of logistics services export.

The most interesting region from the analyzed position, geographically located on the border of Europe and Asia at the intersection of transport routes from one end of Russia to the other, is the Ural region. Regional logistics systems can be considered as indicators of the transformation of Russia's participation in the GVCs in terms of the qualitative and quantitative composition of commodity and material flows. Let's look at how the development of global logistics is represented in regional development documents. The Strategy of social and economic development of the Sverdlovsk region for 2016-2030 [10] identifies the favorable position of the Sverdlovsk region for the transport and logistics complex, as well as the availability of affordable natural production energy and human resources. At first glance, the analyzed document identifies priorities of social and economic policy, such as creating competitive conditions for the accumulation and preservation of human potential, creating conditions for increasing the competitiveness of industrial innovation and entrepreneurial potential, as well as balanced development of territories. There is no doubt that the assessment of such advantages is aimed at strengthening the global economic factors that influence the region's role in the GVCs. The document also notes the predominance of the region's raw material role as a negative factor in the global world chains, which can be considered as a political prerequisite for the participation of regional authorities in the development of their role in the GVCs. However, in actual measures, a specific direction for the development of transport and logistics services that ensure the inclusion of the region in the global chains and transport routes of the Euro-Asian region is not proposed. Investment policy is not linked to the comprehensive development of the logistics base of the transport and logistics system. This, in our opinion, does not allow to fully realize the existing potential for economic development of the Ural region. This approach in regional policy formation does not allow to identify new ways to develop Russia's role in the GVCs, related to the change of the raw material role to the role of a high-tech supplier of logistics services in the global processes of commodity flows.

As we have already defined above, the export of transport and logistics services can play a key role in the transformation of Russia's raw material role towards high-tech participation [11]. Export of transport and logistics services refers to services provided by residents of the national economy to non-residents.

Based on the established standards, operations performed by resident transport companies as transport services in logistics are established: transportation of Russian export cargoes from the customs border of the Russian Federation to the destination specified by the importer; transportation of imported Russian goods on the territory of the country, exporting goods to the Russian Federation; transit of goods belonging to non-residents not related to the Russian export or import of the goods through the territory of the Russian Federation ("international transit); transit through the territory of foreign countries or between foreign countries belonging to non-residents of goods not related to the Russian export or import of goods. At the same time, financial currency flows must cross the border of Russia. The transfer of cargo abroad and payment for transportation by a Russian resident of a Russian transport company made in rubles is not considered an export of transport services. 


\section{Conclusions}

The study has shown that the role of Russia in the GVCs is defined as a raw material with a high degree of participation [2, p. 2]. A promising way to transform this role in the direction of transition to the provision of high-tech and, in the future, innovative services is to strengthen the role of regional transport and logistics systems in the direction of developing the export of transport services.

As institutional conditions ensuring the development and transformation of regional transport and logistics systems, which act as subsystems of global logistics, in the direction of the transition to the export of high-tech transport services, it is necessary to consider the following:

inclusion of regional transport and logistics systems development as one of the leading target vectors in the strategic programs of regional, interregional and federal development, this will ensure the implementation of a systematic approach to investment, technology policy, quality assurance and innovative development of transport and logistics services, as well as the logistics integration of the main components of regional economic systems development in the direction of transition from mining to high-tech processing industries;

development of regional tax support tools (investment tax deduction, etc.) for organizations that carry out real international cargo transportation and maintain world standards of their quality;

active use and development of the compensation mechanism for exporters of the Ural region when attracting Russian vehicles for sending products abroad;

systematic development of regional legislation in the direction of targeted regional programs formation in the framework of the goals and objectives of the national project "International cooperation and export" in relation to the specification and expansion of the role of transport and transport and logistics services export.

\section{References}

1. World Bank. 2020. World Development Report 2020: Trading for Development in the Age of Global Value Chains (Washington, DC: World Bank)

2. Connecting to Compete 2018 Trade Logistics in the Global Economy. The Logistics Performance Index and Its Indicators (The International Bank for Reconstruction and Development/The World Bank, 2018)

3. S. Miroudot, UNCTAD Multi-Year Expert Meeting On Trade, Services and Development, 11 (2017).

4. I.P. Gurova, I. V. Korsakova, News of the Volgograd State Technical University 16, 113-117 (2016)

5. V.G. Varnasky, Modern Europe 1, 86 (2019)

6. S.N. Reznikov, Bulletin of the Rostov State University of Economics (RINKh).1, 53 (2016)

7. M.A. Volkova, Yu.V. Yerygin, Bulletin of the North Caucasus Federal University 6, 69 (2018)

8. Regional integration: towards an inclusive value chain strategy, 117 (Santiago: United Nations, ECLAC, 2014)

9. E.Sh. Akbulatov, Yu.V. Erygin, M.A. Volkova, Management of social and economic systems 1, 13 (2019)

10. On the strategy of social and economic development of the Sverdlovsk region for 2016-2030, Law of the Sverdlovsk region, dated 21.12.2015 № 151-OZ 
11. V.A. Blaginin, D.A. Karkh, E.V. Kolotnina, Journal of Environmental Management and Tourism, 8 (3), 657-665 (2017) doi:10.14505/jemt.v8.3(19). 17. 